\title{
Aggression traits in youth psychopathy: the key role of serotonin
}

\section{Carmelo M. Vicario*}

School of Psychology, Bangor University, Bangor, UK

*Correspondence: carmelo.vicario@uniroma1.it

Edited by:

Ashok Mysore, St. John's Medical College Hospital, India

Reviewed by:

Pradeep Johnson, St. John's Medical College Hospital, India

Keywords: psychopathic traits, childhood, development, serotonin, behavior

\section{A commentary on}

The neurobiology of psychopathic traits in youths

by Blair RJ (2013). Nat Rev Neurosci 14, 786-99. doi: 10.1038/nrn3577

In a recent article, Blair (1) addresses the neurobiological mechanisms underlying psychopathic traits in childhood. The analysis conducted by the author provides a complete view about the complexity of neuro-functional factors underlying childhood psychopathy. In particular, the author focuses on the role played by structural, endocrinological, genetic, and environmental factors.

Surprisingly, this article offers limited attention to the growing body of evidence about the role of serotonin in aggression (2) and emotional empathy (3), two important aspects of psychopathy, although the author mentioned the effect of the serotonin transporter polymorphism in developing aggression (4) as well as the impact played by serotonin depletion in the recognition of fearful expressions [i.e., Ref. (5)].

The literature provides strong support to the suggestion that the pediatric origin of psychopathy might be grounded on serotoninergic abnormalities. Kruesi et al. (6) examined the cerebrospinal fluid levels of 5-hydroxyindoleacetic acid, a metabolite of serotonin, in relation to aggression, impulsivity, and social functioning in 29 children and adolescents with disruptive behavior disorders. The cerebrospinal fluid 5-hydroxyindoleacetic acid level was low compared with that of age-, sex-, and race-matched patients with obsessivecompulsive disorder.
Further insights are also provided by the study of borderline personality disorder (BPD), which onset might occur during childhood and adolescence (7). This disorder is characterized by impulsive aggressive behaviors, such as physical aggression directed toward others, self-mutilation, and domestic violence (8). Soloff et al. (9) have reported that patients with BPD have diminished response to serotonergic stimulation in areas of prefrontal cortex.

A relationship between serotoninergic abnormalities and aggression has been reported also in patients with anorexia nervosa (AN), an eating disorder typical of the pre-puberal and adolescence period (10). This disorder is characterized by marked disgust sensitivity for food $(11,12)$, but also by impulsivity and aggressive behavior. For example, Fava et al. (13) reported that the $28 \%$ of AN suffers have experienced uncontrollable anger attack compared with four $(10 \%)$ of the control subjects. These symptoms can be explained in relation to a reduced serotonin activity in underweight patients with AN (14). The increased aggressive behavior in this clinical population could be indirectly caused by a lack of tryptophan (TRP), which is involved in the synthesis of serotonin (15). In fact, subjects on hypocaloric diets have reduced serotonin activity and show reduced TRP availability (16). Moreover, acute TRP depletion has been associated to aggression in young people with $\mathrm{ADHD}$ (17), while it has been reported that TRP integration contributes to behavioral regulation in boys with history of behavior regulation difficulties.

An indirect evidence in support of the current issue is also provided by role played by genetic variation of the serotonin transporter-linked polymorphic region (5HTTLPR) in the connectivity of two key regions of psychopathy in youths (1) such as the amygdale (18) and the anterior cingulate cortex (19).

Finally, serotoninergic abnormalities may be called into question to explain the effects of negative experiences, such as childhood traumatization, in developing psychopathic traits. This is suggested by research on sexual abuse. Sexually abused women homozygous for the lowactivity monoamine oxidase A allele, a gene involved in the synthesis of serotonin (20), had high rates of antisocial symptoms as compared to sexually abused woman who are homozygous for the high activity allele (21). According to this evidence, one could argue that serotonin plays a role not only with respect to a specific episode of violence and/or aggression (i.e., related to a particular context or state) but it represents an element of predisposition, which might actively contribute to the inclusion and consolidation of violence and aggression as a trait of personality, if exposed to particular (i.e., negative) experience. In this sense, serotonin can be considered relevant at trait level as suggested by Sadeh et al. (22).

Overall, the evidence discussed above provides support to the key role of serotonin in explaining the neurobiological origin of psychopathic symptoms in youths such as aggression. This is suggested not only by the direct effect of this monoamine on social behavior but also by its role, at genetic level, in determining the vulnerability to environmental experiences associated to antisocial and aggressive conducts. However, one must keep in mind that antisocial behavior is not synonymous 
of psychopathy $(23,24)$. Indeed, as noted by Hare (25), about the $90 \%$ of psychopathic aggressors meet criteria for antisocial personality disorders (APD), but only the $25 \%$ of individuals diagnosed with APD are psychopaths. Moreover, although the main goal of this article is to highlight the role of serotonin in aggressive behavior, it should be clarified that this tract can be influenced by other neurochemical factors. In this regard, the nitric oxide (NO) seems to play an important role (26). For example, it has been shown that the absence of the gene for the synthesis of the nitric oxide increases aggression in mice (27). This evidence extends the spectrum of the neurochemical factors involved in aggression and, at the same time, provides an explanation to the negative studies that has not reported a direct relationship between low levels of serotonin and aggression [i.e., Ref. (28)].

Finally, in the context of serotonin, it is important to provide a distinction between "impulsive aggression" and "premeditate aggression." In fact, as reported by Linnoila et al. (29), serotonin was significantly lower in subjects affected by "impulsive violence" while the levels of this monoamine did not change significantly in the "premeditated violence" sample. This suggests that serotonin seems mainly implied in the impulsivity associated to aggression rather than aggression itself.

In summary, we have seen that serotonin appears to be of paramount importance in explaining aggression as trait of personality rather than as a reaction elicited by the context.

\section{REFERENCES}

1. Blair RJ. The neurobiology of psychopathic traits in youths. Nat Rev Neurosci (2013) 14:786-99. doi:10.1038/nrn3577

2. Stanley B, Molcho A, Stanley M, Winchel R, Gameroff MJ, Parsons B, et al. Association of aggressive behavior with altered serotonergic function in patients who are not suicidal. Am J Psychiatry (2000) 157:609-14. doi:10.1176/appi.ajp.157. 4.609

3. Crockett MJ, Clark L, Hauser MD, Robbins TW. Serotonin selectively influences moral judgment and behavior through effects on harm aversion. Proc Natl Acad Sci U S A (2010) 107:17433-8. doi:10.1073/pnas.1009396107

4. Viding E, Hanscombe KB, Curtis CJ, Davis OS, Meaburn EL, Plomin R. In search of genes associated with risk for psychopathic tendencies in children: a two-stage genome-wide association study of pooled DNA. J Child Psychol Psychiatry (2010) 51(7):780-8. doi:10.1111/j.1469-7610. 2010.02236.x
5. Dadds MR, Perry Y, Hawes DJ, Merz S, Riddell AC, Haines DJ, et al. Attention to the eyes and fearrecognition deficits in child psychopathy. Br J Psychiatry (2006) 189:280-1. doi:10.1192/bjp.bp.105. 018150

6. Kruesi MJ, Rapoport JL, Hamburger S, Hibbs E, Potter WZ, Lenane $\mathrm{M}$, et al. Cerebrospinal fluid monoamine metabolites, aggression, and impulsivity in disruptive behavior disorders of children and adolescents. Arch Gen Psychiatry (1999) 47:419-26. doi:10.1001/archpsyc.1990. 01810170019003

7. Bradley R, Conklin CZ, Westen D. The borderline personality diagnosis in adolescents: gender differences and subtypes. J Child Psychol Psychiatry (2005) 46:1006-19. doi:10.1111/j.1469-7610.2004. 00401.x

8. Goodman M, New A. Impulsive aggression in borderline personality disorder. Curr Psychiatry Rep (2000) 2:56-61. doi:10.1007/s1 1920-000-0043-1

9. Soloff PH, Meltzer CC, Greer PJ, Constantine D, Kelly TM. A fenfluramine-activated FDGPET study of borderline personality disorder. Biol Psychiatry (2000) 47:540-7. doi:10.1016/S00063223(99)00202-4

10. Gordon I, Lask B, Bryant-Waugh R, Christie D, Timimi S. Childhood onset anorexia nervosa: towards identifying a biological substrate. Int J Eat Disord (1997) 22(2):159-65. doi:10.1002/(SICI) 1098-108X(199709)22:23.3.CO;2-5

11. Vicario CM, Crescentini C. Punishing food: what brain activity can tell us about the representation of food in recovered anorexia nervosa. Biol Psychiatry (2012) 71(8):e31-2. doi:10.1016/j.biopsych.2011. 10.036

12. Vicario CM. Altered insula response to sweet taste processing in recovered anorexia and bulimia nervosa: a matter of disgust sensitivity? Am J Psychiatry (2013) 170:1497. doi:10.1176/appi.ajp.2013. 13060748

13. Fava M, Rappe SM, West J, Herzog DB. Anger attacks in eating disorders. Psychiatry Res (1995) 56:205-12. doi:10.1016/0165-1781(95)02577-J

14. Kaye WH, Gwirtsman HE, George DT, Jimerson DC, Ebert MH. CSF 5-HIAA concentrations in anorexia nervosa: reduced values in underweight subjects normalize after weight gain. Biol Psychiatry (1988) 23:102-5. doi:10.1016/0006-3223(88) 90113-8

15. Leathwood PD. Tryptophan availability and serotonin synthesis. Proc Nutr Soc (1987) 46(1):143-56. doi:10.1079/PNS19870018

16. Anderson IM, Parry-Billings M, Newsholme EA, Fairburn CG, Cowen PJ. Dieting reduces plasma tryptophan and alters brain 5-HT function in women. Psychol Med (1990) 20:785-91. doi:10. 1017/S0033291700036473

17. von Polier GG, Biskup CS, Kötting WF, Bubenzer S, Helmbold $K$, Eisert A, et al. Change in electrodermal activity after acute tryptophan depletion associated with aggression in young people with attention deficit hyperactivity disorder (ADHD). J Neural Transm (2013). doi:10.1007/ s00702-013-1119-5

18. Fang Z, Zhu S, Gillihan SJ, Korczykowski M, Detre JA, Rao H. Serotonin transporter genotype modulates functional connectivity between amygdala and PCC/PCu during mood recovery. Front Hum Neurosci (2013) 7:704. doi:10.3389/fnhum. 2013.00704
19. Waring JD, Etkin A, Hallmayer JF, O'Hara R. Connectivity underlying emotion conflict regulation in older adults with 5-HTTLPR short allele: a preliminary investigation. Am J Geriatr Psychiatry (2013) pii: S1064-7481(13):335-7. doi:10.1016/j. jagp.2013.08.004

20. Caspi A, McClay J, Moffitt TE, Mill J, Martin J, Craig IW, et al. Role of genotype in the cycle of violence in maltreated children. Science (2002) 297:851-4. doi:10.1126/science. 1072290

21. Widom CS, Brzustowicz LM. MAOA and the "cycle of violence": childhood abuse and neglect, MAOA genotype, and risk for violent and antisocial behavior. Biol Psychiatry (2006) 60:684-9. doi:10.1016/j. biopsych.2006.03.039

22. Sadeh N, Javdani S, Jackson JJ, Reynolds EK, Potenza MN, Gelernter J, et al. Serotonin transporter gene associations with psychopathic traits in youth vary as a function of socioeconomic resources. J Abnorm Psychol (2010) 119:604-9. doi:10.1037/a0019709

23. Rutter M. Psychopathy in childhood: is it a meaningful diagnosis? Br J Psychiatry (2012) 200:175-6. doi:10.1192/bjp.bp.111.092072

24. Ribeiro da Silva D, Rijo D, Salekin RT. Child and adolescent psychopathy: a state-of-the-art reflection on the construct and etiological theories. J Crim Justice (2012) 40:269-77. doi:10.1016/j. jcrimjus.2012.05.005

25. Hare RD. A comparison of procedures for the assessment of psychopathy. J Consult Clin Psychol (1985) 53:7-16. doi:10.1037/0022-006X. 53.1.7

26. Bedrosian TA, Nelson RJ. Nitric oxide and serotonin interactions in aggression. Curr Top Behav Neurosci (2013). doi:10.1007/7854_2013_273

27. Nelson RJ, Demas GE, Huang PL, Fishman MC, Dawson VL, Dawson TM, et al. Behavioural abnormalities in male mice lacking neuronal nitric oxide synthase. Nature (1995) 378:383-6. doi:10.1038/ $378383 \mathrm{a} 0$

28. Booij L, Tremblay RE, Leyton M, Séguin JR, Vitaro F, Gravel P, et al. Brain serotonin synthesis in adult males characterized by physical aggression during childhood: a 21-year longitudinal study. PLoS One (2010) 5(6):e11255. doi:10.1371/ journal.pone.0011255

29. Linnoila M. Low cerebrospinal fluid 5hydroxyindoleacetic acid concentration differentiates impulsive from nonimpulsive violent behavior. Life Sci (1983) 33:2609-14. doi:10.1016/0024-3205(83)90344-2

Received: 09 January 2014; accepted: 02 March 2014; published online: 17 March 2014.

Citation: Vicario CM (2014) Aggression traits in youth psychopathy: the key role of serotonin. Front. Psychiatry 5:25. doi: 10.3389/fpsyt.2014.00025

This article was submitted to Child and Neurodevelopmental Psychiatry, a section of the journal Frontiers in Psychiatry.

Copyright (c) 2014 Vicario. This is an open-access article distributed under the terms of the Creative Commons Attribution License (CC BY). The use, distribution or reproduction in other forums is permitted, provided the original author(s) or licensor are credited and that the original publication in this journal is cited, in accordance with accepted academic practice. No use, distribution or reproduction is permitted which does not comply with these terms. 